\title{
Lumpy Skin Disease in Calves: The Association Between Clinical Signs and Biochemical Alterations
}

\section{Sherin R. Rouby ${ }^{1 *}$, Olfat Shehata ${ }^{2}$, Ahmed S. Abdel-Moneim ${ }^{3}$, Khaled H. Hussein ${ }^{1}$, Mourad MaHmoud MaHmoud ${ }^{4}$}

${ }^{1}$ Department of Veterinary Medicine (Infectious Diseases), Faculty of Veterinary Medicine, Beni-Suef University, Beni-Suef 62511, Egypt; ${ }^{2}$ Department of Clinical Pathology, Faculty of Veterinary Medicine, Beni-Suef University, Beni-Suef 62511, Egypt; ${ }^{3}$ Department of Microbiology, College of Medicine, Taif University, Al-Taif, Saudi Arabia; ${ }^{4}$ Department of Animal Medicine, Faculty of Veterinary Medicine, Beni-Suef University, Beni-Suef 62511, Egypt.

\begin{abstract}
Lumpy skin disease (LSD) is an acute, sub-acute and chronic devastating disease of cattle. The current study was performed to determine various alterations in some haemato-biochemical parameters in calves naturally infected with lumpy skin disease virus (LSDV). Two groups of calves were enrolled in the study. The first group included nine Laboratory confirmed LSDV infected calves and the second group included five healthy calves. Laboratory confirmation was conducted by polymerase chain reaction (PCR) flanking the partial RPO30 gene. Blood samples were collected from all calves and subjected to hematological and biochemical analyses. The total mean leukocytic counts, lymphocytes, and monocytes in the LSDV infected calves were significantly higher than those in the control group. In addition, the total protein, total creatine kinase (CK), aspartate aminotransferase (AST), blood urea nitrogen (BUN), creatinine and potassium levels showed significant high values in LSDV infected calves while cholesterol levels were significantly lowered when compared to healthy ones. Serum gamma glutamyl transferase (GGT) activity, serum albumin, globulins and sodium levels did not show significant difference in calves in different groups. Results of both hematology and biochemistry profiles obtained from calves reflect the severe inflammatory process associated with natural LSD infection.
\end{abstract}

Keywords | Hemato-biochemical, Calves, Lumpy skin disease, PCR, RPO30 gene

Received | July 06, 2021; Accepted | July 27, 2021; Published | September 25, 2021

*Correspondence | Olfat Shehata, Department of Clinical Pathology, Faculty of Veterinary Medicine, Beni-Suef University, Beni-Suef 62511, Egypt; Email: Olfat_shehata@yahoo.com

Citation | Rouby SR, Shehata O, Abdel-Moneim AS, Hussein KH, Mahmoud MM (2021). Lumpy skin disease in calves: The association between clinical signs and biochemical alterations. Adv. Anim. Vet. Sci. 9(11): 1863-1868.

DOI | http://dx.doi.org/10.17582/journal.aavs/2021/9.11.1863.1868

ISSN (Online) | 2307-8316; ISSN (Print) | 2309-3331

Copyright (C) 2021 Rouby et al. This is an open access article distributed under the Creative Commons Attribution License, which permits unrestricted use, distribution, and reproduction in any medium, provided the original work is properly cited.

\section{INTRODUCTION}

$\mathrm{L}$ umpy skin disease (LSD) is one of the most economically important cattle diseases not only in Africa, Middle East but also in Europe and Asia. Although the mortality rate is usually low (10\%), economic losses result from damaged hides, decreased milk production, abortion, loss of traction power, poor growth, weight loss, and infertility (Tuppurainen and Oura, 2012). The disease is caused by a lumpy skin disease virus (LSDV). LSDV is a member of the genus Capripoxvirus (CaPV) within the family Poxviridae (Buller et al., 2005). Sheep pox virus (SPPV) and goat pox virus (GTPV) share LSDV in the genus and are closely related to it (Maclachlan and Dubovi, 2011).

LSD may occur as an acute, sub-acute or chronic form and cause mild to severe symptoms. Clinical signs of LSD include fever, the appearance of raised, circular, firm nodules on the skin, skin edema, and lymphadenitis (Tuppurainen et al., 2005). Lesions also develop on the mucous membranes of mouth, nostrils, and respiratory tract, with subsequent pneumonia (Tuppurainen and Oura, 2012). The severity of clinical signs of LSD and its 
timeline of infection depend on the host immune status, age, sex and breed type (OIE, 2010). Diseases and factors which overwhelmed the immune status of the animal such as blood parasite in Egypt might add to the severity of LSD infection. In general, young animals often have more severe disease and develop lesions within 24 to $48 \mathrm{~h}$ (AlSalihi, 2014). Fine-skinned breeds are considered the more vulnerable breeds to LSD infection such as HolsteinFriesian (H-F) and Jersey breeds (Davies, 1991; Babiuk et al., 2008).

Clinical signs are highly suggestive and pathognomonic to LSD. The clinical diagnosis is confirmed by using either conventional polymerase chain reaction (PCR) (Ireland and Binepal, 1998; Heine et al., 1999) or real time PCR (Lamien et al., 2011b). Several reports shed light on the possibility of utilizing the alterations in some hematological and biochemical parameters to help better understanding the pathogenesis and prognosis of the disease.

These alterations can be observed when cellular or organ damage occurs. In case of viral diseases cellular damage takes place when the virus replicates in essential cells sufficiently and destroys them directly or damages organ function indirectly through cytotoxic immune response towards viral infected cells (Baron et al., 1996).

There is a lack of knowledge about the hematological and serum biochemical findings of calves naturally infected with LSDV. The purpose of the current study was to investigate the changes in hematological and biochemical parameters in calves naturally infected with LSDV.

\section{MATERIALS AND METHODS}

\section{EPIDEMIOLOGICAL DATA}

The present study was conducted in a small village in ELWasta, Beni-Suef, Egypt where a sporadic outbreak of LSD occurred during September: November 2019 after arrival of an apparently health bull purchased from ElBeheira, Egypt on 22 of August 2019. By September 1, 2019 the bull suffered from clinical signs typical to LSD. After one week (7/9/2019) the bull died. By September 15,2019 a calf in-contact with the bull suffered from the same signs. From 17/9/2019 through 26/11/2019 a total of eight cases were observed in the neighboring premises. The village had a history of vaccination against LSD with sheep pox vaccine (Yugoslavian RM65 strain) nine months before the onset of the outbreak.

\section{Animals}

A total of 14 male and female calves ageing 8-11 months were included in the present work. Nine calves showed the characteristic clinical signs of LSD were selected as LSDV infected group. Five healthy calves of the same age and breed free from blood parasites were used as control group. Calves were thoroughly examined, and the clinical findings were recorded (Table 1$)$.

Table 1: Data of calves.

\begin{tabular}{|c|c|c|c|}
\hline \multicolumn{3}{|c|}{ No. Animal data } & \multirow[t]{2}{*}{ Clinical signs } \\
\hline & Species/breed & Age & \\
\hline 1 & Calf/Friesian & 9 Month & $\begin{array}{l}\text { Fever, skin nodules, edema } \\
\text { in limb, Pneumonia } \\
\text { followed by death after a } \\
\text { course of one week }\end{array}$ \\
\hline 2 & Calf/Friesian & 10 Month & $\begin{array}{l}\text { Fever, skin nodules and } \\
\text { edema in limb }\end{array}$ \\
\hline 3 & Heifer/Baladi & 8 Month & Fever, skin nodules \\
\hline 4 & Heifer/Baladi & 11 Month & Fever, skin nodules \\
\hline 5 & Heifer/Crossbreed & 11 Month & $\begin{array}{l}\text { Fever, skin nodules and } \\
\text { edema in limb }\end{array}$ \\
\hline 6 & Calf/Baladi & 8 Month & Fever, skin nodules \\
\hline 7 & Heifer/Crossbreed & 9 Month & $\begin{array}{l}\text { Fever, skin nodules and } \\
\text { edema in limb and dewlap }\end{array}$ \\
\hline 8 & Calf/Baladi & 11 Month & Fever, skin nodules \\
\hline 9 & Calf/Friesian & 10 Month & Fever, skin nodules \\
\hline
\end{tabular}

\section{ETHICAL APPROVAL}

All clinical samples were collected as per standard sample collection procedure without giving any harm or stress to the animals. The present work was approved by the Ethical Commetee for Medical Research at the College of Veterinary Medicine, Beni-Suef University and Animal Care Guidelines of the General Organization for Veterinary Services, Egypt.

\section{SAMPLES}

\section{Tissue SAmples}

Skin nodules were surgically extirpated after the skin was locally anesthetized with $2 \%$ lidocaine then placed in glycerol saline and stored at $-20^{\circ} \mathrm{C}$ for PCR analysis.

\section{BLOOD SAMPLES}

Approximately, $6 \mathrm{ml}$ of blood per calf was drawn aseptically from Jugular vein, of which 2 ml of blood was transferred to a sterile vial containing disodium ethylenediaminetetraacetic (EDTA) for leukocytic examination and PCR. The remaining $4 \mathrm{ml}$ of blood was transferred to vacutainer tube for serum separation. Serum samples were kept at $-20{ }^{\circ} \mathrm{C}$ till used for biochemical examination.

\section{PCR}

DNA was extracted from collected skin lesions and blood using a DNA Mini Kit (Thermo, Germany) according to the manufacturer's instructions. 
PCR run was performed using primer set targeting RP030 gene with following sequences; forward primer: F 5'-TCTATGTCTTGATATGTGGTGGTAG-3 and reverse primer: $\mathrm{R}$ 5'-AGTGATTAGGTGGTGTATTATTTTCC-3 and expected amplicon size 172bp (Lamien et al., 2011a). PCR amplification was conducted using PCR master mix (Thermo, USA) in a total volume of $25 \mu \mathrm{l} / \mathrm{reac}-$ tion. The thermal profile started by an initial denaturation at $94^{\circ} \mathrm{C}$ for 4 minutes, followed by 35 cycles of denaturation at $94^{\circ} \mathrm{C}$ for 45 second, annealing at $55^{\circ} \mathrm{C}$ for 45 second and extension at $72^{\circ} \mathrm{C}$ for 1 minute and a final extension at $72^{\circ} \mathrm{C}$ for 7 minutes. $\mathrm{PCR}$ products were electrophoresed in $2 \%$ agarose gel containing ethidium bromide at $100 \mathrm{~V}$ for 30 minutes and visualized in trans-illuminator.

\section{LEUKOGRAM ANALYSIS}

Leucogram profile was done within one hour after sample collection. Both total and differential leucocytic counts were estimated according to Feldman et al. (2000).

\section{BiOCHEMICAL ANALYSIS}

The harvested serum was used to measure total protein, albumin, aspartate aminotransferase (AST), GGT, CK, blood urea nitrogen (BUN), creatinine, cholesterol and serum sodium and potassium concentrations. Biochemical analyses were conducted by spectrophotometrically using commercially available diagnostic kits (Diamond diagnostics, Holliston, United states) according to manufacturer's instructions.

\section{RESULTS}

\section{Clinical findings}

The LSDV infected calves (LSD group) exhibited the following clinical signs; inappetence, dullness, high fever $\left(40.70 \pm 0.25^{\circ} \mathrm{C}\right.$ vs. $38.68 \pm 0.24^{\circ} \mathrm{C}$ in affected and control calves, respectively), increased respiratory and heart rates $(39.46 \pm 1.16$ vs. $25.62 \pm 1.18$ and $91.60 \pm 1.24$ vs. $57.20 \pm 1.64$ in affected and control calves, respectively). Firm circumscribed skin nodules about $0.5-5 \mathrm{~cm}$ in diameter in skin accompanied with enlargement of superficial lymph nodes especially prescapular and precrural lymph nodes were detected. Skin nodules were distributed in various body parts involving the neck, chest, abdomen, limbs, perineal area, and muzzle (Figure 1). Excessive salivation, lacrimation and nasal discharge were also noted in all naturally infected calves. Edematous swelling of dewlap one or more legs with lameness were observed in four animals (two Friesian calves and two crossbreed heifer) and one of them were suffered from pneumonia followed by death after a course of one week.

\section{Detection of VIRAL DNA by PCR}

Viral DNA was identified in all skin lesions collected from diseased calves $(n=9)$ and was negative in all control animals $(n=5)$. The RPO30 gene-based PCR generated PCR products with a length of $172 \mathrm{bp}$ (Figure 2).

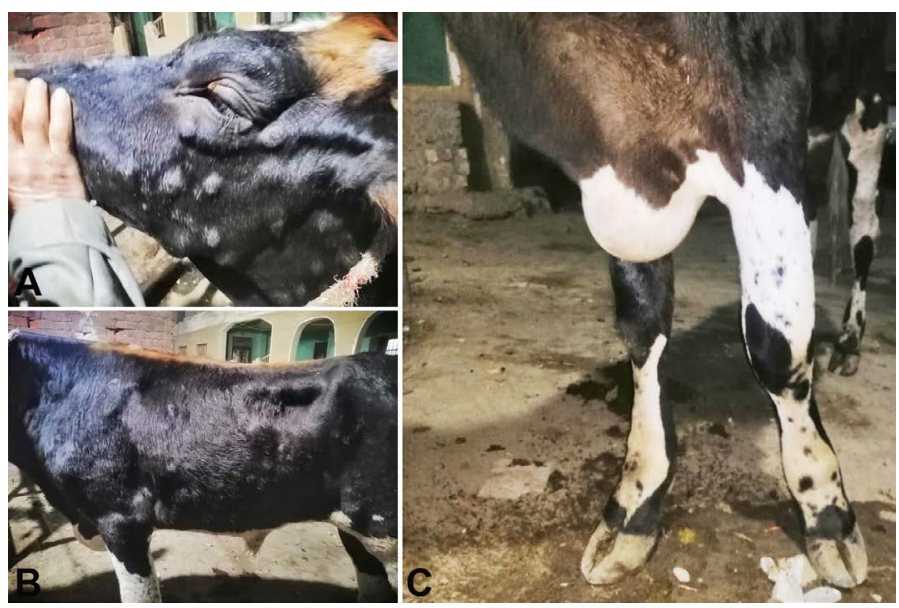

Figure 1: Clinical sings of LSD, A. Cutaneous nodules on the head and neck regions, B. lumps on different body regions with enlargement of superficial lymph nodes. C. Edema in the dewlap and fore limb

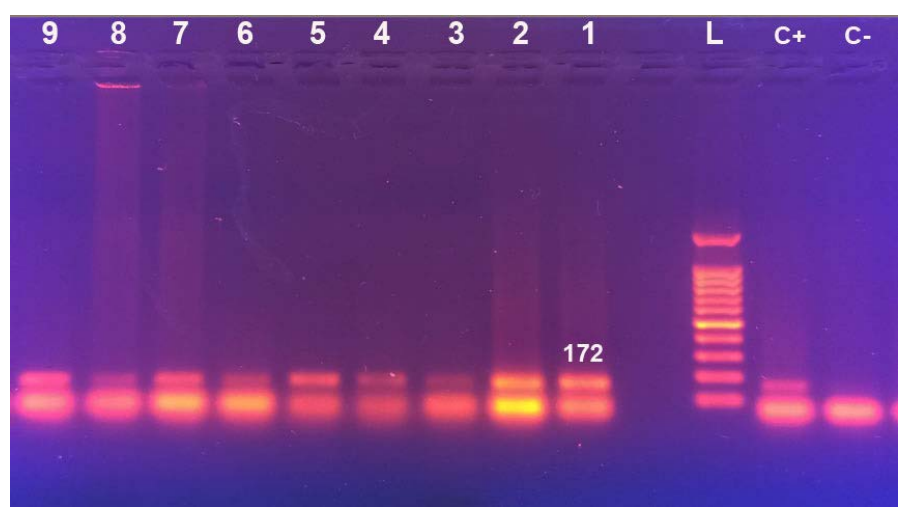

Figure 2: Gel electrophoresis of RPO30 gene-based PCR C-: control negative, C+: control positive, L: 100bp DNA ladder, Lane 1:9: naturally LSDV infected calves samples

\section{LEUKOGRAM AND BIOCHEMICAL ANALYSIS}

Results of leucogram showed significant leukocytosis accompanied with lymphocytosis and monocytosis in LSDV infected calves when compared to control group (Table 2). The total protein, total CK, AST, BUN, creatinine and potassium levels showed significant high values while cholesterol levels significantly lowered in diseased calves when compared to healthy one. Serum albumin, globulins, A/G ratio, Serum GGT activity and sodium levels were not significantly altered (Table 2).

\section{DISCUSSION}

Transfer of subclinically infected animal already incubating the disease is considered one of the main risk factors for LSD spread (Tuppurainen and Oura, 2012). In the current study the illegal movement of an apparently health bull is assumed to be responsible for the development of 
such outbreak. The appearance of severe clinical signs in calves is attributed to the lack of either passive or active immunity against LSD. The last vaccination against LSD in the village was conducted in January 2019, at that time the calves were aging less than 3 months of age therefore they received no vaccine shots with no history of exposure to field infection until the beginning of the outbreak. On clinical examination, calves were suffered from high fever, firm circumscribed skin nodules about $0.5-5 \mathrm{~cm}$ in diameter in skin accompanied with enlargement of superficial lymph nodes especially prescapular and precrural lymph nodes. Excessive salivation, lacrimation and nasal discharge were also noted in all naturally infected calves. Edematous swelling of one or more legs with lameness were observed in four animals (two Friesian calves and two crossbreed heifer) and one of them was suffered from pneumonia followed by death after a course of two weeks. All these lesions were reported previously by Prozesky and Barnard (1982); Coetzer (2004); Awadin et al. (2011) and prove that LSD is more severe in Friesian and crossbreed than native breed.

Table 2: Alteration in some haematological and biochemical parameters in calves naturally infected with $\mathrm{LSDV}($ mean $\pm \mathrm{SE})$.

\begin{tabular}{|c|c|c|}
\hline & Control & $\begin{array}{l}\text { Naturally } \\
\text { infected calves }\end{array}$ \\
\hline $\operatorname{TLC}\left(\mathrm{x} 10^{3 /} / \mathrm{ul}\right)$ & $6.11 \pm 0.20$ & $8.45 \pm 0.15$ ** \\
\hline Lymphocytes (x 103/ul) & $3.47 \pm 0.11$ & $4.54 \pm 0.09 *$ \\
\hline Neutrophils (x 103//ul) & $2.17 \pm 0.28$ & $3.13 \pm 0.23$ \\
\hline Monocytes (x 103//ul) & $0.27 \pm 0.02$ & $0.42 \pm 0.05^{*}$ \\
\hline Eosinophils (x 10/ul) & $0.20 \pm 0.04$ & $0.36 \pm 0.09$ \\
\hline $\operatorname{AST}(\mathrm{U} / \mathrm{L})$ & $55.33 \pm 2.26$ & $142.12 \pm 3.92^{* * *}$ \\
\hline CK (U/L) & $98.67 \pm 1.86$ & $183.31 \pm 8.82^{* *}$ \\
\hline GGT (U/L) & $24.66 \pm 2.40$ & $20.00 \pm 1.52$ \\
\hline Creatinine (mg/dl) & $1.14 \pm 0.01$ & $1.31 \pm 0.05^{*}$ \\
\hline BUN (mg/dl) & $18.33 \pm 0.88$ & $26.67 \pm 2.23^{*}$ \\
\hline Cholesterol (mg/dl) & $212.00 \pm 1.53$ & $61.33 \pm 0.89^{* * *}$ \\
\hline $\mathrm{Na}(\mathrm{mmol} / \mathrm{L})$ & $131.50 \pm 1.76$ & $148.67 \pm 7.86$ \\
\hline $\mathrm{K}(\mathrm{mmol} / \mathrm{L})$ & $5.03 \pm 0.023$ & $6.03 \pm 0.37$ \\
\hline Total protein (g/dl) & $6.37 \pm 0.19$ & $7.54 \pm 0.29^{*}$ \\
\hline Albumin (g/dl) & $3.46 \pm 0.13$ & $4.10 \pm 0.28$ \\
\hline Globulin (g/dl) & $2.91 \pm 0.23$ & $3.43 \pm 0.36$ \\
\hline $\mathrm{A} / \mathrm{G}$ ratio & $1.19 \pm 0.02$ & $1.20 \pm 0.10$ \\
\hline
\end{tabular}

Significant $* \mathrm{P} \leq 0.05^{* *} \mathrm{P} \leq 0.01{ }^{* * *} \mathrm{P} \leq 0.001$.

PCR is the best technique for quickly detecting and identifying the causative agent of the examined viral outbreak. PCR targeting RPO30 gene were confirm the presence of LSDV in skin lesions collected from affected calves. RPO30 gene-based PCR assay according to Lamien et al. (2011a) affords a simply approach for CaPV classification and aids in the swift differentiation between GTPV/ LSDV and SPPV without the requisite of DNA sequencing (Rouby, 2018).

Differential leucocytic count of the blood samples obtained from naturally infected calves showed a significant leukocytosis accompanied with neutrophilia,lymphocytosis and monocytosis as compared to control group. This result in agreement with Abutarbush (2015). On the contrary, El-Shoukary et al. (2019) reported leucopenia in a LSD infected bull. This is probably related to the stage and severity of infection (Ahmed, 2015). In cattle, leukopenia is usually seen in the developmental stage of the acute infection, after which the production of neutrophils is intensified, leading to leukocytosis (Morris, 2002). Leukocytosis could be due to secondary acute bacterial infections, especially pyogenic bacterial infections as reported by Ahmed (2015). Viral diseases and chronic inflammatory condition might be causes for lymphocytosis. Monocytosis can occur any time that neutrophilia occurs, because both cell lines are derived from a common bipotential stem cell. Monocytosis may be observed in both acute and chronic stages of disease (Latimer, 2011).

Regarding serum biochemical findings, most calves naturally infected with LSDV had hyperproteinemia. Hyperproteinemia in the present study could be due to dehydration. On the other hand, hyperproteinemia associated with the inflammatory leukogram confirm the presence of severe inflammatory condition as reported by Baron et al. (1996). It is known that LSDV replicates in pericytes, endothelial cells and probably some cells in blood vessel and lymph vessel walls. This fact results in severe vasculitis and lymphangitis in affected areas with proliferation of lymphocyte (Prozesky and Barnard, 1982). Vasculitis was also reported in a small number of vessels $(<10)$ in organs other than the skin and associated musculature, including the kidney, small intestine, and cardiac muscle which called Extracutaneous LSDV lesions (Bernardo et al., 2020). Extracutaneous lesions have been reported previously in muscle, liver, rumen and lung of premature calf with LSD (Rouby and Aboulsoud, 2016). This explains the elevation of AST, total CK, creatinine and the potassium levels in calves suffered from LSD. AST present in the hepatocytes, skeletal muscle and muscular cardiac cells and its elevation may be attributed to the muscular injuries. LSD lesions was previously reported in the muscle fascia, in the skeletal muscles (Barnard et al., 1994) and cardiac muscles (Vasatova et al. 2013; Sevik et al., 2016).

The hyperkalemia and the significant increase in the total CK detected in the current study might be attributed 
to the muscular damage (Hoffmann and Solter, 2008) or metabolic acidosis associated with LSD infection (Radostitis et al., 2000; Carlson, 2002). However, Marmor et al. (1988) indicated that CK levels might be elevated due to cardiac injury. Renal affections might be a cause of hypekalemia.

A significant increase in the level of serum creatinine and blood urea nitrogen in diseased calves were observed in comparison with apparently healthy animals. It has been stated that an increase in creatinine level reflects a decrease in the glomerular filtration rate (Gowda et al., 2010; Samra and Abcar, 2012). High serum urea and creatinine levels in LSDV naturally infected animals agree with other previously published results (Helmy et al., 2017). According to Morris and Johnston (2002), A significant increase in blood urea nitrogen in diseased animals might be attributed to anorexia, the direct effect of LSDV on the kidneys, loss of muscle mass, increased protein catabolism and reduced renal blood flow during the viraemic stage of LSD. A decrease in serum total cholesterol level in the diseased calves is in agreement with that found in other viral infectious diseases and stressful conditions in the ruminant animals (Fernandez et al., 2011). Hypocholesterolemia may be due to impaired cholesterol absorption as a sequela of vasculitis in small intestine of LSDV infected animals as Bernardo et al. (2020). Under stressful diseased condition, hypocholesterolemia may occur as a result of enhanced rate of macrophage-specific reverse cholesterol transport, increased transit of cholesterol through the large intestine, and increased fecal bile acid excretion (Silvennoinen et al., 2015).

\section{CONCLUSIONS AND RECOMMENDATIONS}

Application of some laboratory investigations (including some hematological and biochemical parameters) in correlation with clinical signs may serve in diagnosis of LSD.

\section{NOVELTY STATEMENT}

The study describes The Association Between Clinical Signs of LSD and Biochemical Alterations in naturally infected calves.

\section{AUTHOR'S CONTRIBUTION}

Sherin Rouby, Olfat Shehata and Morad Mahmoud designed the study and performed laboratory works, Ahmed S. Abdel-Moneim reviewed the manuscript, Khaled Hussein collected the Field samples.

\section{CONFLICT OF INTEREST}

The authors have declared no conflict of interest.

\section{REFERENCES}

-Abutarbush, SM (2015). Hematological and serumbiochemical findings in clinical cases of cattle naturally infected with lumpy skin disease. J. Infect. Dev. Ctries, 9: 283-288. https:// doi.org/10.3855/jidc.5038

-Ahmed N (2015). Immunological, hematological, biochemical, and histopathological studies on cows naturally infected with lumpy skin disease. Vet. World, 8(9): 1131-1136. https://doi. org/10.14202/vetworld.2015.1131-1136

-Al-Salihi KA (2014). Lumpy skin disease: Review of literature. MRVSA. 3(3): 6-23.

-Awadin W, Hussein H, Elseady Y, Babiuk S, and Furuoka H (2011). Detection of lumpy skin disease virus antigen and genomic DNA in formalin-fixed paraffin-embedded tissues from an Egyptian outbreak in 2006. Transbound. Emerg. Dis., 58: 451-457. https://doi.org/10.1111/j.18651682.2011.01238.x

-Babiuk S, Bowden TR, Parkyn G, Dalman B, Manning L, Neufeld J, Embury, Hyatt C, Copps J, Boyle DB (2008). Quantification of lumpy skin disease virus following experimental infection in cattle. Transbound. Emerg. Dis., 55: 299-307. https://doi.org/10.1111/j.18651682.2008.01024.x

- Barnard BJ, Munz E, Dumbell K, Prozesky L (1994). Lumpy skin disease. In: Coetzer, J.A.W., Thomson, G.R., Tustin, R.C. (Eds.), Infectious Diseases of Livestock with Special Reference to Southern Africa, vol. 1. Oxford University Press, Cape Town, pp. 604-612.

-Baron S, Fons M, Albrecht T (1996). Viral pathogenesis, in medical microbiology, S. Baron, Ed., chapter 45, University of Texas Medical Branch at Galveston, Galveston, Tex, USA, $4^{\text {th }}$ edition.

- Bernardo B, Haga IR, Wijesiriwardana N, Hawes PC, Simpson, Morrison LR, MacIntyre N, Brocchi E, John Atkinson J, Haegeman A, De Clercq K, Darpel KE, Beard PM (2020). Lumpy skin disease is characterized by severe multifocal dermatitis with necrotizing fibrinoid vasculitis following experimental infection. Vet. Pathol., 57(3): 388-396. https:// doi.org/10.1177/0300985820913268

- Buller RM, Arif BM, Black DN, Dumbell KR, Esposito JJ, Lefkowitz EJ, McFadden G, Moss B, Mercer AA, Moyer RW, Skinner MA, Tripathy DN (2005). Poxviridae. In Fauquet CM, Mayo MA, Maniloff J, Desselberger U, Ball LA, editors. Virus taxonomy: Eight report of the international committee on the taxonomy of viruses. Oxford: Elsevier Academic Press. pp. 117-133.

- Carlson GP (2002). Clinical chemistry tests. In Smith BP, editor. Large animal internal medicine, $2^{\text {nd }}$ edition. New York: Mosby. pp. 389-414.

- Coetzer J, Tuppurainen E (2004). Lumpy skin disease, vol 2. Oxford University Press, Southern Africa, pp. 1-12.

-Davies FG (1991). Lumpy skin disease of cattle: A growing problem in Africa and the Near East. World Anim. Rev., 68: 37-42.

-E1-Shoukary R, Nasr-eldin DN, Osman AS (2019). Change in behavior, blood parameters and pain score in response to different treatment strategies in bull infected with FMD or LSD. Int.J. Vet. Sci., 1(1): 82-107.https://doi.org/10.21608/ 


\section{svu.2019.6807.1004}

- Feldman B, Zinkl J, Jain N (2000). Schalms veterinary hematology. $5^{\text {th }}$ ed., Lea and Febiger, Philadelphia, USA.

-Fernandez-Sirera L, Mentaberre G, Lopez-Olvera JR, Cuenca R, Lavin S, Marco, I (2011). Haematology and serum chemistry of Pyrenean chamois (Rupicapra pyrenaica) naturally infected with a border disease virus. Res. Vet. Sci., 90(3): 463-467. https://doi.org/10.1016/j.rvsc.2010.06.021

- Gowda S, Desai PB, Kulkarni SS, Hull VV, Math AAK, Vernekar SN (2010). Markers of renal function tests. North Am. J. Med. Sci., 2(4): 170-173.

- Heine HG, Stevens MP, Foord AJ, Boyle DB (1999). A capripoxvirus detection PCR and antibody ELISA based on the major antigen $\mathrm{P} 32$, the homolog of the vaccinia virus H3L gene. J. Immunol. Methods, 227: 187-196. https:/doi. org/10.1016/S0022-1759(99)00072-1

- Helmy NM, Ahmed AS, Mohamed ZY (2017). Molecular, clinico-pathological and sero-diagnosis of LSDV in cattle at sharkia and fayoum governorates. J. Virol. Sci., 1: 1-11.

-Hoffmann WE, Solter PF (2008). Chapter 12 diagnostic enzymology of domestic animals A2 Kaneko, J. Jerry. In: Harvey JW, Bruss ML (eds) Clinical biochemistry of domestic animals, sixth edn. Academic Press, San Diego, pp. 351-378. https://doi.org/10.1016/B978-0-12-3704917.00012-X

-Ireland DC, Binepal YS (1998). Improved detection of Capripox virus in biopsy samples by PCR. J. Virol. Methods, 74(1): 1-7. https://doi.org/10.1016/S0166-0934(98)00035-4

- Lamien CE, Le Goff C, Silber R, Wallace DB, Gulyaz V, Tuppurainen E, Madani H, Caufour P, Adam T, Harrak M, El-Luckins AG, Albina E, Diallo A (2011a). Use of the Capripox virus homologue of Vaccinia virus $30 \mathrm{kDa}$ RNA polymerase subunit (RPO30) gene as a novel diagnostic and genotyping target: Development of a classical PCR method to differentiate goat poxvirus from sheep poxvirus. Vet. Microbiolol., 149(1-2): 30-39. https://doi.org/10.1016/j. vetmic.2010.09.038

- Lamien CE, Lelenta M, Goger W, Silber R, Tuppurainen E, Matijevic M, Luckins AG, Diallo A, (2011b). Real time PCR method for simultaneous detection, quantitation and differentiation of capripox viruses. J. Virol. Methods, 171(1): 134-140. https://doi.org/10.1016/j.jviromet.2010.10.014

- Latimer KS (2011). Duncan and prasse's veterinary laboratory medicine: Clinical pathology, $5^{\text {th }}$ edition. Wiley-Blackwell ISBN: 978-0-813-82014-9 July 2011.

- Maclachlan N, Dubovi E (2011). Fenner's veterinary virology, $4^{\text {th }}$ edn. Academic Press, New York.

- Marmor AT, Klein R, Plich M, Groshar D, Schneeweiss A (1988). Elevated CK-MB isoenzyme after exercise stress test and atrial pacing in patients with ischemic heart disease. Chest. 94(6): 1216-1220. https://doi.org/10.1378/ chest.94.6.1216
-Morris DD (2002). Alterations in the leukogram. In Smith BP, editor. Large Animal Internal Medicine, $2^{\text {nd }}$ edition. New York: Mosby. pp. 420-426.

- Morris DD, Johnston JK (2002). Alterations in blood protein. In: Large animal internal medicine. Smith, B.P. (ed.), $2^{\text {nd }}$ edn. New York: Mosby, pp. 427-433.

- OIE, World Organization for Animal Health (2010). Terrestrial manual of lumpy skin disease, Chapter 2.4.14. Version adopted by the World Assembly of Delegates of the OIE in May 2010, OIE, Paris.

-Prozesky L, Barnard BJH (1982). A study of the pathology of lumpy skin disease in cattle. Onderstepoort J. Vet. Res., 49(3): 167-175.

- Radostitis OM, Gay CC, Blood DC, Hinchcliff KW, (2000). Diseases caused by viruses and chlamydia II. In Radostitis OM, Gay CC, Blood DC, editors. Veterinary Medicine: A Textbook of the Diseases of Cattle Horses Sheep Pigs and Goats, 9th edition. Philadelphia: WB Saunders Co. pp. $1135-1260$.

- Rouby S, Aboulsoud E (2016). Evidence of intrauterine transmission of lumpy skin disease virus. Vet. J., 209: 1 93195. https://doi.org/10.1016/j.tvj1.2015.11.010

- Rouby SR (2018). RPO30 gene based PCR for detection and differentiation of lumpy skin disease virus and sheep poxvirus field and vaccinal strains. Vet. Sci. Res. Rev., 4(1): 1-8. https://doi.org/10.17582/journal.vsrr/2018.4.1.1.8

- Samra M,Abcar A (2012). False estimates of elevated creatinine. Permanente J., 16(2): 51-52. https://doi.org/10.7812/ TPP/11-121

-Sevik M,Avci O,Dogan M,Ince OB (2016). Serum biochemistry of lumpy skin disease virus-infected cattle. Biomed. Res. Int., 2016: 6257984. https://doi.org/10.1155/2016/6257984

- Silvennoinen R, Quesada H, Kareinen I, Julve J, Kaipiainen L, Gylling H, Blanco-Vaca F, Escola-Gil JC, Kovanen PT, Lee-Rueckert M (2015). Chronic intermittent psychological stress promotes macrophage reverse cholesterol transport by impairing bile acid absorption in mice. Physiol. Rep., 3(5): 1-15. https://doi.org/10.14814/phy2.12402

-Tuppurainen ESM, Oura CAL (2012). Review: Lumpy skin disease: An emerging threat to Europe, the Middle East and Asia. Transbound. Emerg. Dis., 59(1): 40-48. https://doi. org/10.1111/j.1865-1682.2011.01242.x

-Tuppurainen S, Venter E, Coetzer J (2005). The detection of lumpy skin disease virus in samples of experimentally infected cattle using different diagnostic techniques. Onderstepoort. J. Vet. Res., 72: 153-164. https://doi.org/10.4102/ojvr. v72i2.213

-Vasatova M, Pudil R, Horacek JM, Buchler T (2013). Current applications of cardiac troponin $\mathrm{T}$ for the diagnosis of myocardial damage. Adv. Clin. Chem., 61: 33-65. https:// doi.org/10.1016/B978-0-12-407680-8.00002-6 